\title{
Implementasi pendidikan agama Kristen yang relevan dalam masyarakat majemuk sebagai dimensi misi gereja
}

\author{
Setrianto Tarrapa \\ Institut Agama Kristen Negeri Toraja, Sulawesi Selatan \\ Correspondence: z3.tarrapa@gmail.com
}

https://orcid.org/00000002-8558-8151

Keywords:

Christian religious

education;

mission;

plural society;

pluralism;

majemuk;

masyarakat majemuk;

misi gereja;

pendidikan agama Kristen

\section{Article History}

Submitted: June 25, 2021

Revised: September 15, 2021

Accepted: October 02, 2021

DOI: https://doi.org/ 10.30995/kur.v7i2.308

Copyright: (02021, Authors.

License:

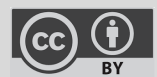

Scan this QR,

Read Online

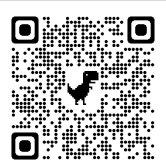

Abstract: The reality of pluralism in the context of Indonesia on the one hand, is a challenge towards the implementation of Christian Religious Education. However, on the other hand, Christian Religious Education is becoming very essential for Christians to demonstrate the love of God in the midst of society. Christians are always in touch with adherents of other religions, even that kind of relationship feels so strong in various areas of life. This problem triggers how the idea of implementing Christian Education is relevant in the pluralistic context in Indonesia. This study was analyzed using qualitative research methods through library research techniques. Findings showed that, in the pluralistic context, the implementation of Christian Religious Education in Indonesia as an integral part of the mission can be carried out through three aspects, namely: revitalizing the thinking paradigm about pluralism; interpreting the implementation strategy of Christian Religious Education in a pluralistic society and mainstreaming and building the vision and mission of multicultural based Christian Religious Education.

Abstrak: Realitas kemajemukan dalam konteks Indonesia di satu sisi merupakan tantangan terhadap pelaksanaan pendidikan agama Kristen; namun di sisi lain, pendidikan agama Kristen menjadi amat penting bagi orang Kristen untuk mendemonstrasikan kasih Allah di tengah-tengah masyarakat. Orang orang Kristen selalu bersentuhan dengan penganut agama lain, bahkan sentuhan itu terasa amat kuat dalam berbagai bidang kehidupan. Permasalahan ini memicu bagaimana gagasan pelaksanaan Pendidikan Kristen yang relevan dalam konteks majemuk di Indonesia. Kajian ini ditelaah dengan menggunakan metode penelitian kualitatif melalui teknik pustaka. Hasil temuan menunjukkan bahwa dalam konteks majemuk penyelenggaraan Pendidikan agama Kristen di Indonesia sebagai bagian integral misi dapat dilakukan melalui tiga aspek yaitu: merevitalisasi paradigma berpikir tentang kemajemukan; mereinterpretasi strategi pelaksanaan Pendidikan agama Kristen dalam masyarakat yang majemuk; serta mengarusutamakan dan membangun visi dan misi pendidikan agama Kristen berbasis multikultural.

\section{Pendahuluan}

Secara faktual, muncul sebuah kesadaran baru bahwa manusia tidak lagi hidup dalam sebuah komunitas homogen, melainkan sudah dalam heterogenitas. Manusia dari berbagai latar belakang budaya, etnis, agama bahkan berbagai latar belakang telah hidup dalam satu komunitas, saling berinteraksi satu dengan yang lain. Interaksi dalam sebuah komunitas heterogen sebagai realitas sosial yang tidak bisa dihindari melainkan harus dihidupi, dengan kata lain manusia tidak 
lagi hidup dalam pengkotak-kotakan karena kesadaran primordialisme, tetapi hidup berbaur secara sadar oleh pihak yang berbeda latar belakang.

Indonesia adalah negara yang mendasarkan dirinya pada falsafah "Bhinneka Tunggal Ika" yang berarti berbeda-beda tetapi tetap satu. Dari falsafah ini menunjukkan bahwa Indonesia bersifat heterogen (majemuk). Keberadaan kemajemukan meliputi semua kawasan di seluruh Indonesia yang dipicu oleh faktor sosial ekonomi, politik, pendidikan, dan lain-lain. Situasi pluralistik dalam bidang keagamaan juga semakin intensif dan dirasakan menjadi bagian hidup masyarakat, menyebabkan sebuah pergeseran nyata yaitu satu komunitas keagamaan yang semula hidup secara homogen berubah menjadi komunitas yang hidup bersama melalui perjumpaan dan interaksi dengan orang beragama lain. Realitas kemajemukan muncul dan berkembang sangat terkait dengan perkembangan peradaban manusia termasuk era globalisasi yang membuat manusia memiliki kebebasan dalam bergerak, berinteraksi, bahkan berdomisili dalam suatu komunitas untuk membangun kehidupan yang lebih baik.

Konteks masyarakat inilah yang gereja hadir di dalamnya untuk mengemban misi panggilan sebagai umat kepunyaan Allah. Gereja bukanlah komunitas yang kaku melainkan persekutuan yang misioner yang harus mengemban misi kerajaan Allah sampai penggenapan amanat itu yang bertitik tolak pada konsep kehidupan yang utuh dalam hidup damai dan sejahtera. M. Einar Sitompul mengatakan bahwa pusat penyiaran atau misi gereja adalah Injil atau Gospel yang pada intinya adalah penyampaian kabar baik kepada semua orang. Tujuan dalam misi tersebut adalah bukanlah pertambahan jumlah anggota gereja melainkan menciptakan kehidupan yang lebih baik, yang sudah barang tentu dimulai dari mempercayai Allah. ${ }^{1}$ Sehingga misi gereja bertitik tolak pada damai sejahtera untuk semua, atau dengan istilah syalom.

Meskipun konsep ideal misi gereja demikian, namun realitasnya tidaklah demikian. Misi gereja dipahami orang-orang Kristen sebagai upaya melucuti orang lain untuk masuk dalam persekutuan gereja, sehingga persepsi orang lain juga turut mengikuti paham demikian yaitu misi dipandang sebagai proses pengkristenisasian. Inilah sikap yang sangat keliru terhadap maksud misi yang diberikan kepada gereja. Persepsi yang keliru tersebut menjadi pemicu munculnya kesempatan untuk menjadikannya titik berangkat terjadinya konflik. Secara logisnya misi berjalan jika kehadiran orang Kristen berdampingan, bekerja sama dengan orang yang berkeyakinan lain tanpa dibayangi rasa tegang, rasa mencurigai, rasa takut, tanpa permusuhan, melainkan suasana anggun yang mempesona yaitu interaksi yang bermakna. Jikalau konsep keliru dari dari orang Kristen tidak dijembatani maka tidak akan mungkin kerukunan beragama terealisasi. Bahkan, rasa curiga mencurigai ada pada setiap penganut agama yang pada akhirnya bangsa yang bersatu terpecah belah yang berujung pada konflik.

Seiring perkembangan zaman, pendidikan Kristen memainkan peranan penting, karena di satu sisi Pendidikan Agama Kristen (PAK) adalah hal esensial bagi gereja, karena PAK adalah tugas hakiki dari gereja sejak gereja awal mula hingga gereja masa kini, sementara di lain pihak PAK sebagaimana pendidikan pada umumnya merupakan media transformasi sosial. Dalam konteks masyarakat majemuk peranan PAK menjadi amat penting karena gereja selalu bersentuhan dengan penganut agama lain, bahkan sangat terasa dalam semua aspek kehidupan. PAK berperan penting supaya gereja dapat mengaplikasikan imannya dengan baik yaitu tidak menghindari realitas sekitanya, melainkan dengan berlandaskan kasih mendemostrasikan kasih Allah di tengah-tengah dunia. Dalam kerangka fungsi yang demikian luas, pendidikan Kristen seyogianya didesain sebagai penggambaran ideal tentang pluralisme.

Kajian ini menekankan tentang implementasi PAK yang relevan dalam konteks majemuk di Indonesia. Kajian ini diperkaya oleh penelitian terdahulu, antara lain Pemikiran Spritualitas PAK Ekumenis-trasformatif²; pemikiran Antone S. Hope yang berfokus pada Mempertimbangkan Ke-

${ }^{1}$ Einer M. Sitompul, Gereja Menyingkapi Perubahan ( Jakarta: BPK Gunung Mulia, 2004), 53-54.

${ }^{2}$ Djois Anneke Rantung, Pendidikan Agama Kristen dalam Kehidupan Masyarakat Majemuk (Yogyakarta: Lintang Rasi Aksara Books, 2017). 
majemukan dalam Pendidikan Agama3; bahkan pemikiran Yonki Karman tentang Menggagas Pendidikan Agama Inklusif4. Kajian ini bertitik tolak dari kondisi implementasi PAK yang cenderung memiliki pandangan lama yaitu PAK dibatasi pada matapelajaran kepada nara didik Kristen; PAK ditengarai pendekatan simbolik, ritual, legal formalistik; PAK masih bertumpuh pada aspek kognitif; PAK masih cenderung ekslusif. Kecenderungan ini menunjukkan kegagalan PAK bahkan berdampak negatif dalam konteks majemuk atara lain memicu terjadinya konflik. Oleh karena itu tujuan dalam research ini adalah menganalisis langkah strategi PAK yang relevan dalam masyarakat majemuk sebagai dimensi misi gereja.

\section{Metode Penelitian}

Dalam penyusunan penelitian ini, digunakan pendekatan penelitian kualitatif pada jenis deskriptif kualitatif yaitu penelitian yang memberi penekanan quality tentang masalah-masalah sosial. Pendekatan ini sangat relevan karena ditinjau dari esensi topik ini, maka peneliti mengesplor fenomena-fenomena yang tidak dapat dikuantifikasi melainkan mendeskripsikan situasi nyata melalui uraian-uraian yang bertitik tolak dari pengumpulan dan analisis data yang relevan. Pengumpulan data melalui telaah pustaka secara kritis dan mendalam terhadap dokumen yang relevan. Dalam penelitian ini, sumber data berupa buku, artikel, majalah yang memuat tentang kemajemukan di Indonesia, Pendidikan Kristen dalam konteks Majemuk.

\section{Pembahasan}

\section{Kemajemukan Sebagai Konteks Pelaksanaan Pendidikan Agama Kristen}

Kemajemukan merupakan keanekaragaman atau kebhinnekaan, yang pada umumunya dikenakan dalam kehidupan komunitas masyarakat yang kompleks. Kompleksitas sebuah masyarakat meliputi berbagai sendi kehidupan, misalnya ideologi, politik, sosial, dan budaya. Pada sisi lain kemajemukan atau pluralitas berarti adanya keberagaman dalam tiap unsur pembentuk sendi kehidupan, artinya dari tiap-tiap sendi ideologi, politik, sosial, dan budaya tersebut tidak hanya terdiri dari satu kesamaan tertentu, melainkan terdiri dari berbagai keragaman pula. Theo Kobong mengemukakan bahwa di tengah kehidupan yang pluralitas terjadilah interaksi kebudayaan, agama dan lain-lain, yang mengedepankan soal kebenaran yang sering terjadi benturan. Dari kenyataan pluralistis itu muncullah pemahaman pluraslisme yaitu paham bahwa pada hakikatnya dalam semua agama, paling tidak ada nilai-nilai kebenaran, atau kebenaran itu bukanlah monopoli satu agama. ${ }^{5}$

Dalam bingkai sejarah Indonesia, pluralitas telah menjadi identitas yang ada sejak bangsa Indonesia lahir. Perjumpaan dan interaksi semakin kompleks seiring perkembangan era globalisasi. Bangsa Indonesia adalah percampuran antara berbagai jenis polarisasi yang sulit untuk terkristalisasi sebagai sebuah entitas budaya yang homogen. Kemajemukan di Indonesia yang dominan bersentuhan dengan pelaksanaan PAK adalah kemajemukan agama dan kemajemukan kultural. Pertama, kemajemukan agama secara faktual bahwa agama besar di dunia yang berkembang di Indonesia serti Kristen, Islam, Hindu, Budha, Kong Hu Cu. Selain itu masih bertumbuhnya aliran-aliran kepercayaan lainnya seperti Kaharingan di Kalimantan, aluk todolo di Toraja. keberagama agama di Indonesia pada prinsipnya tidak hanya dilihat dalam beragamnya agama yang dianut tetapi juga dilihat dari paham yang dianut dari komunitas beragama. Banawiratma menekankan bahwa terjadinya heterogenitas internal agama atau beragamnya mazhab dalam agama muncul sebagai implikasi dari perbedaan analisis terhadap situasi konkrit

\footnotetext{
${ }^{3}$ Antone S. Hope, Pendidikan Kristiani Kontekstual : Mempertimbangkan Realitas Kemajemukan dalam Pendidikan Agama, Terjemahan Mariam sutanto (Jakarta: BPK Gunung Mulia,2010).

${ }^{4}$ Yonky Karman, "Menggagas Pendidikan Agama Inklusif," Kompas 12 Juni 2002.

${ }^{5}$ Teo Kobong, "Gereja Memasuki Abad ke-21," dalam Seri membangun bangsa Agama Dalam Praksis, diselaraskan Bambang Subandrijo (Jakarta: BPK Gunung mulia, 2003), 178.
} 
dan perbedaan hermeneutik terhadap tradisi iman yang bersumber dari kitab suci. ${ }^{6}$ Kemajemukan agama sampai masa kini, sudah menjadi persoalan teologis yang terpaut dengan sebuah kebenaran itu sendiri dan berimplikasi pada munculnya sikap kristiani terhadap kemajemukan agama yaitu sikap yang menitikberatkan bahwa keuniversalan Yesus Kristus sebagai satu satunya penyelamat dunia; respon kedua menitikberatkan pada keyakinan bahwa Allah menyatakan diri kepada agama-agama lain melalui penyataan umum namun hanya melalui Yesus Kristus manusia diselamatkan; dan respon ketiga adalah menitikberatkan keyakinan bahwa ada anugerah keselamatan secara universal namun anugerah Kristus sebagai tolak ukur.

Kemajemukan kultural sebagai fakta kedua dilihat dalam dua kacamata yaitu di satu pihak berdasarkan teritorial atau kawasan domisili atau suku etnik. Patrick Johnstone dalam Santoso, menekankan bahwa Indonesia adalah negara paling multi etno-linguistik sesudah Papua Nugini. Indonesia terdiri dari 702 etno-linguistik yang berbeda-beda. Kepelbagaian etnis tersebut menyebabkan perbedaan budaya antar kelompok-kelompok dalam masyarakat? ${ }^{7}$. Sementara di sisi lain kemajemukan kultur juga dilihat dalam bingkai kategorial yaitu dalam sebuah komunitas masyarakat tidak lagi hidup seprofesi melainkan beragam profesi baik tani, buruh, pegawai negeri, karyawan, pelajar, profesional, dan profesi lainnya. Sebuah fenomena menarik bahwa masyarakat mencari komunitas persekutuan yang dapat menjawab pergumulan kesehariannya.

Kemajemukan berpotensi untuk menimbulkan konflik jika tidak ditanggapi dengan baik. Pendidikan Agama Kristen (PAK) sebagai dimensi misi gereja perlu menanggapi secara sungguhsungguh dan menerima kemajemukan sebagai kenyataan sekaligus sebagai ladang misi. Pada satu pihak melalui PAK mengajak nara didik untuk mensyukuri kemajemukan sebagai anugerah Tuhan yang menjadi sumber-sumber bermanfaat untuk membangun harmonisasi bersama umat manusia dan seluruh ciptaan. PAK yang dilaksanakan dalam konteks yang majemuk harus menerobos tembok prasangka religius, sebagaimana Yesus tembok pemisah (Yoh. 4:1-42).

\section{Langkah Strategis Implementasi PAK dalam Masyarakat Majemuk Sebagai Dimensi Misi Gereja}

Pemahaman misi dalam bidang pendidikan Kristen tidak bisa dilepaskan dari pemahaman misi gereja secara keseluruhan. Bukan hanya karena bukti sejarah bahwa pendidikan menjadi alat yang memegang peranan penting untuk pekabaran Injil tetapi juga karena hakekat pendidikan itu adalah bagian integral misi gereja yaitu pembebasan, dan kemitraan. Pendidikan tidak hanya menjadikan pemerdekaan sebagai sasaran melainkan dijadikan sebagai syarat mutlak bagi terselenggaranya pendidikan yang humanis secara baik dan benar. Pendidikan yang membebaskan mencakup dua dimensi yaitu penyadaran dan prakarsa nara didik. Penyadaran adalah awal terjadinya proses pembebasan dan dari kesadaran manusia menjadi kreatif.

Misi pendidikan nampak dalam penatalayanan (kemitraan ciptaan). Alkitab menyaksikan bahwa manusia ciptaan Allah yang memiliki tiga dimensi yang jelas yaitu manusia terhubung dengan Allah (dimensi spritual), manusia terhubung dengan sesamanya (dimensi sosial), serta manusia diberi tanggung jawab untuk memelihara ciptaan lain (dimensi kultural). Sebagaimana Allah bersedia menjadikan manusia sebagai mitra-Nya maka manusia harus membangun relasi yang baik dengan seluruh ciptaan, dengan Allah dan sesamanya (Manusia punya dimensi religious, social, dan cultural). Singkatnya bahwa muatan misi gereja terhadap Pendidikan Agama Kristen adalah meliputi kerygma (pemberitaan), dan didaktik (pengajaran).

Dalam konteks Indonesia seringkali muncul paham yang sempit tentang Pendidikan agama Kristen yaitu mereka memahami dan mempergunakan istilah Pendidikan Agama Kristen dengan mengacu hanya pada maksud matapelajaran agama Kristen di sekolah formal atau Perguruan

\footnotetext{
${ }^{6}$ J. B. Banawiratma, Iman, Pendidikan dan Perubahan Sosial (Yogyakarta: Kanisius, 1991), 47.

7 Iman Santoso, "Memasuki Abad XXI Umat Kristiani dalam Pergumulan Jati Diri Serta Pembangunan Bangsa yang Terus Menerus," dalam Peran Serta Gereja dalam Pembangunan Nasional, Peny. Weinata S.(Jakarta: Sinar Harapan,1998), 174.
} 
Tinggi. Sementara PAK adalah salah satu bagian dari panggilan gereja. Ruang lingkup PAK mencakup semua bentuk usaha pelayanan atau pembinaan yang diselenggarakan secara sadar, teratur, dan terus menerus secara berkesinambungan yang dilakukan gereja bagi warga dalam setting anak-anak, remaja, pemuda, sampai dewasa. Sehingga matapelajaran di sekolah hanyalah bagian integral dari PAK, namun menjangkau massa yang sangat besar. ${ }^{8}$

Dalam pengalaman historis, satu momentum yang tidak bisa dilupakan bagi perkembangan pendidikan yaitu bangkitnya nasionalisme pada tahun 1970-an yang berintikan timbulnya gagasan pendidikan multicultural. Konsekuensi dari gagasan ini pendidikan multikultural atas tujuan pendidikan diterima sebagai ancaman paling serius oleh gereja dalam peranannya di bidang pendidikan sejak Edik Milano (313), yaitu ketika agama Kristen diterima sebagai agama resmi oleh kaisar Konstantinus. Dalam semangat nasionalisme yang memberi ruang bagi kemajemukan kultural, gereja cenderung melestarikan konsep lama yang tidak memberikan tempat kepada gagasan multikultural. ${ }^{9}$

Sementara kemajemukan agama dan budaya di Indonesia merupakan ciri khas sejak berabad-abad yang lalu, versi Kekristenan yang diperkenalkan oleh penginjil Eropa adalah Kekristenan yang berkembang dalam lingkungan budaya dan paradigma berpikir yang tidak cukup peka, bahkan tidak memberi ruang bagi kemajemukan. ${ }^{10}$ Sekarang muncul pergumulan, yaitu bagaimana strategi yang harus dibangun sehingga PAK merupakan wadah memberitakan Injil dalam masyarakat majemuk?

Kemajemukan di Indonesia adalah anugerah Tuhan yang harus dipelihara dan dilestarikan sebagai identitas bangsa Indonesia, namun tidak dapat disangkal dan diragukan juga bahwa kemajemukan berpotensi dapat menghancukan sebuah masyarakat. Gereja dalam tugas PAKnya sangat perlu menangani masalah tersebut secara sungguh-sungguh dan menerima kemajemukan sebagai kenyataan, supaya Injil yang dapat diberitakan melalui wadah PAK dapat bermanfaat bagi masyarakat, manusia pada keseluruhan. Gereja harus belajar secara berkesinambungan melihat dan menerima tangan Tuhan bekerja di dalam dan melalui kemajemukan.

Keberadaan Indonesia yang majemuk menjadi pertimbangan kuat bagi gereja untuk berupaya merumuskan ulang langkah strategi pelaksanaan pendidikan Kristen yang tepat dalam konteks tersebut supaya tidak terasing dalam konteksnya melainkan eksistensinya semakin diterima masyarakat bahkan nara didik mampu mengimplementasikan imannya dalam konteksnya secara benar dan tepat. Pemberitaan Injil tidak terlepas dari realitas kemajemukan. Sikap triumpalistik yang melekat pada Kekristenan yang berkembang di Eropa dan datang di Indonesia harus direvitalisasi dengan memperhatikan konteks di mana gereja berkembang. Pendekatan dalam pendidikan yang lebih menekankan superioritas agama Kristen sangatlah tidak menolong warga gereja/ nara didik untuk merealisasikan diri secara positif dengan orang yang berkeyakinan lain. Bukan hanya unsur religious, melainkan juga dengan kandungan budaya-budaya lain dan kearifan lokal sarat dengan nilai-nilai edukatif sebagai landasan pengembangan pendidikan bahkan sebagai wadah melaksanakan pendidikan Kristen. Gereja perlu membangun sikap transformatif terhadap kearifan lokal, melalui langkah kajian teologis nilai-nilai dalam kearifan lokal yang bisa ditransformasi secara relevan ke dalam nilai-nilai kristiani.

Sikap yang demikian merupakan sikap yang tidak mengklaim begitu cepat nilai tradisional sebagai budaya kafir yang tidak bisa bersentuhan dengan nilai Injil, melainkan lebih bijaksana menggali nilai-nilai kearifan lokal yang direlevankan dengan nilai-nilai kristiani. Mengemban tugas misi melalui PAK dalam komunitas yang majemuk bukanlah pekerjaan yang mudah melainkan membutuhkan beberapa tahap yang konkrit supaya tujuan dari PAK sebagai pemberitaan

\footnotetext{
${ }^{8}$ Kadarmanto Hardjowasito, "Pendidikan Agama Kristen dalam Konteks Masyarakat Indonesia yang Majemuk," Dalam Berakar di dalam Dia \&Dibangun di atas Dia,Peny. Robert P. Borrong (Jakarta: BPK Gunung Mulia,2002), 107-108.

${ }^{9}$ Ibid, 110.

${ }^{10}$ Marthen Manggeng," Pendidikan Agama Kristen Dalam Masyarakat Majemuk," INTIM: Jurnal Teologi Kontekstual, no.8 (semester genap 2015):23.
} 
Injil dapat tercapai. Oleh Sebab itu langkah strategi pelaksanaan PAK dapat dilakukan dengan beberapa hal berikut:

\section{Merevitalisasi paradigma berpikir tentang kemajemukan}

Secara sadar kita harus mengakui bahwa sebelum kita menemukan konsep pemaknaan kemajemukan yang sebenarnya maka kita tidak akan pernah maju. Kemajemukan bukanlah sesuatu yang menakutkan karena kemajemukan adalah rancangan Tuhan. Kemajemukan bukanlah suatu kekeliruan yang harus dikoreksi oleh gereja karena fakta kemajemukan adalah dimensi yang inheren dari kemanusiaan dan merupakan sumber-sumber yang diberikan oleh Sang Maha Pencipta.

Penerimaan terhadap kemajemukan tidak dimaksudkan untuk mengorbankan pertimbangan-pertimbangan kritis. Sering muncul kesalahpahaman, seolah-olah gereja harus mengesampingkan pertimbangan-pertimbangan kritis agar dapat berperan antar budaya dan antar iman. Namun pada dasarnya bukanlah sikap itu yang dimaksud. Kemajemukan atau pluralitas dijadikan sebagai sebuah kekayaan dan anugerah dari Tuhan yang harus diterima dan dipelihara dengan baik. Pemeliharaan dan penerimaan keadaaan pluralis secara esensial mengerti secara benar, menerima ciri khas masing-masing, serta mewujudkan secara praktis hidup kebersamaan dengan sesama yang berbeda budaya dan keyakinan sebagai artikulasi tujuan yang lebih luhur. Implementasi praktis tersebut berupa unjuk karya bersama, dialog, silahturahmi, serta saling mendukung dalam berbagai dinamika kehidupan yang membangun harmoni kehidupan.

Dasar Alkitab sebagai dasar refleksi sebuah langkah revitasilasi kenyataan kemajemukan adalah teks Kolose 3:9-11. Paulus menekankan bahwa sebagai manusia baru tidak lagi membedakan kemanusiaan lama seseorang, karena di dalam Kristus semua setara satu terhadap yang lainnya. Dalam kemanusiaan lama ada sikap ekslusivisme yang berimplikasi diskriminasi. Kesetaraan kemanusiaan mengisyaratkan pengikut Kristus untuk memperhatikan yang tertindas, sekaligus kesempatanuntuk menghayati kebebasan tanpa dikuasai oleh kehidupan lama yang diskriminatif.

Sangat mendesak gereja lakukan melalui tugas PAK-nya adalah menguji ulang serta mendesain ulang cara membina dan mengasuh iman generasi dan diri sendiri. Fakta memperlihatkan bahwa sampai pada hari ini identitas Kristen telah terbentuk dengan mengabaikan iman dan budaya-budaya lain yang hidup di sekitar. Gereja sering memandang rendah usaha agama lain memperjuangkan dan menciptakan solusi bagi masalah yang dihadapi oleh masyarakat, dengan maksud supaya gereja yang menonjol. ${ }^{11}$

Secara singkat, dalam merevitalisasi paradigma berpikir ini, arah kurikulum Pendidikan Agama Kristen menjadi hal yang vital dan pertama didesain ulang. Tujuan utama revitalisasi adalah melalui penyelenggaraan PAK, di mana peserta didik mampu mengembangkan eksistensi diri secara mandiri, kreatifitas, inovatif sebagai implementasi imannya yang benar dalam lingkungannya, tanpa kehilangan identitas dirinya sebagai Kristen. Praksis PAK secara prinsipil bermuara pada transformasi pengetahuan maupun iman, sebagaimana tujuan PAK dalam konteks majemuk adalah membina warga gereja/nara didik mampu hidup bersama dengan orang lain dalam komunitasnya yang memiliki latarbelakang yang berbeda. Muatan penyenggaraan PAK sebagai arah yang baik dalam memahami kemajemukan sebagai rancangan dan anugerah Tuhan yang harus dipelihara dan dipertanggungjawabkan perlu mengintegrasikan beberapa hal, antara lain:

Pertama, mewujudkan learning together sebagai pilar pendidikan Kristen dalam konteks heterogenitas yaitu melalui proses pendidikan anak didik dimampukan hidup bersama dengan orang lain yang memiliki latar belakang hidup yang beraneka ragam. Dalam perwujudan ini diakui bahwa eksistensi keragaman agama tergantung pada pengembangan sikap toleran, empati dan simpati.

Kedua, Mengedepankan sikap saling percaya karena itu adalah modal membangun masyarakat yang bersifat heterogenitas. Fakta kehidupan dalam pengalaman beragama dan bermasya-

\footnotetext{
${ }^{11}$ Hardjowasito, PAK dalam Kontes Masyarakat Indonesia yang Majemuk, 120
} 
rakat di Indonesia adalah dominan manusia membangun narasi kelompok mayoritas dan minoritas yang menonjolkan sikap saling mencurigai. Dalam situasi demikian Pendidikan agama perlu menanamkan pemahaman yang benar bahwa Indonesia adalah negara yang religius bukan negara agama. Sudah saatnya Umat beragama di Indonesia meninggalkan perdebatan-perdebatan dogmatis dan usaha-usaha persaingan misi memenangkan agama lain, bergeser kepada pemikiran tentang usaha-usaha bersama untuk mengatasi krisis bangsa yang sedang memperpuruk kehidupan Indonesia.

Ketiga, memelihara sikap saling pengertian yaitu kesadaran bahwa setiap orang bebas memilih dan menganut sebuah keyakinan yang tentu memiliki perbedaan dengan nilai-nilai yang dianut atau diimani oleh orang lain. Perbedaan nilai-nilai pada prinsipnya dapat dikelolah untuk saling melengkapi dan memberi kontribusi dalam membangun hubungan yang harmonis. Ada slogan mengatakan bahwa lawan bicara adalah teman berpikir, dan teman berpikir adalah kawan sejati. Artinya dalam kehidupan senantiasa ada kesediaan dan membangun keharmonisan melalui sudut pandang bahwa perbedaan adalah sebuah anugerah dan pada segala kemungkinan dijumpai titik temu antara satu dengan yang lain sebagai nilai hidup bersama. Jadi sangatlah dibutuhkan kedewasaan berpikir dan kedewasaan emosional, sehingga landasan etis sikap kepedulian terhadap sesama dan mengedepankan hidup bersama adalah tanggung jawab Pendidikan agama Kristen.

Keempat, meningkatkan sikap saling menghargai sebagai sikap dasar yang diajarkan oleh agama apapun yaitu menjunjung tinggi harkat dan martabat kesetaraan ciptaan. Inti sari pengajaran agama Kristen menunjuk pada keteladan Yesus yaitu Yesus sebagai Tuhan memberi penghargaan yang tulus kepada umat-Nya. Yesus tidak mempersoalkan latar belakang golongan, budaya dan warna kulit. la mengasihi semua orang dan mengorbankan diri sebagai tebusan bagi semua orang. Jadi dalam konteks plural, sikap saling menghargai harus dibangun dalam PAK yaitu menghargai harkat dan martabat individu atau kelompok/penganut agama lain melalui sikap kesediaan mendengar orang alin yang berbeda latarbelakang.

\section{Mereinterpretasi Strategi Pelaksanaan PAK}

Pada dasarnya, Pendidikan Agama Kristen hadir sebagai bagian tugas panggilan gereja, bukan hanya diperuntukkan bagi segelintir atau sekelompok orang saja, melainkan diperuntukkan pembentukan manusia yang utuh untuk memiliki akhlak dan moralitas yang tinggi dan tercermin pada kepemilikan perilaku, nilai, dan pandangan hidup yang baik. Oleh karena itu sudah saatnya gereja mereinterpretasi ulang strategi pekabaran Injilnya melalui PAK dengan cara meninggalkan pendekatan tradional yang melekat terhadap Zending menuju kepada konteks kehidupan yang sebenarnya yaitu PAK harus diarahkan kepada pembangunan nara didik untuk memiliki indentitas dan komitmen yang jelas tentang imannya dan sekaligus membangun relasi dengan orangorang berkepercayaan lain serta berinteraksi secara positif bukan saling mengorbankan. Dalam mereinterpretasi ulang strategi PAK dalam masyarakat majemuk dan kontekstual, terdapat beberapa komponen yang menjadi vital diperhatikan yaitu: konteks pendidikan agama itu sendiri, isi, tujuan dan prinsip prinsip pendidikan agama Kristen. Hal tersebut tergambar sebagai berikut:

Pertama, pentingnya Pendidikan Agama Kristen dalam konteks masyarakat majemuk. Realitas masyarakat Indonesia yang sangat majemuk, maka pelaksanaan pendidikan agama Kristen tidak bisa dibangun terlepas dari sifat kemajemukan itu. Tidak mungkin gereja mengembangkan PAK dengan mengambil prinsip awal yang seakan-akan membangun diri tanpa bersentuhan dengan kepelbagaian. Pada dasarnya sikap ketertutupan atau ekslusif yang dimiliki oleh gereja bukan baru muncul di Indonesia melainkan sejak dalam umat Israel sebagai pilihan Allah, di mana ekslusif dibangun secara rapi. Mereka memisahkan diri dari bangsa-bangsa kafir bahkan dianggap musuh bebuyutan mereka. Mereka lupa bahwa amanat keterpilihan mereka bukan hanya berlaku bagi dirinya sendiri melainkan keterpilihannya harus menjadi saluran berkat. Bentuk misi pada dasarnya sudah bersifat sentripugal.

Sikap eklusifisme itu, merupakan hal yang mengancam pertumbuhan dan perkembangan PAK di Indonesia, karena PAK menjadi asing dinegerinya sendiri. Sehingga jika mau bertumbuh 
dan berkembang, maka PAK yang harus dibangun adalah PAK yang menjadi ciri khas Indonesia bukan diadopsi secara mentah dari sifat Eropa. Nara didik yang dididik dalam PAK adalah generasi yang menjadi harapan gereja dan masyarakat Indonesia sendiri yang memiliki identitas pluralistik. Pada ciri khas inilah membuka pandangan gereja bahwa gereja tidak lagi mendidik generasi muda dengan mempertentangkan terus menerus perbedaan di anatar agama-agama dan budaya yang ada, karena pendekatan itu hanya untuk memperlihatkan superioritas agama Kristen dan mencari kesalahan agama lain.

Jadi, dalam konteks majemuk nampak bahwa mempelajari hanya satu agama dalam masyarakat majemuk menjadi kegiatan yang tidak memadai dipandang dari hakikat pendidikan. Mengenal dan memahami apa yang diutamakan dalam agama-agama lain melalui pendidikan religius yang dapat dipertanggungjawabkan, akan menjadi modal dasar bagi anak-anak didik untuk menjadi warga masyarakat yang cerdas menghargai kemajemukan dan dihargai oleh masyarakatnya. Atau, dengan kata lain, konteks PAK di Indonesia adalah masyarakat multikultural yang diwarnai dengan kemajemukan dalam agama, kepercayaan dan kebudayaan. Dalam identitas inilah adanya hubungan timbal balik antara PAK dan masyarakat multikultural. Di satu sisi, pendidikan memiliki peran signifikan dalam membangun multikultural, di sisi lain masyarakat multikultural dengan segala karakternya memiliki potensi signifikan untuk keberhasilan fungsi dan peran PAK.

Kedua, Isi pendidikan agama Kristen dalam masyarakat majemuk. Pendidikan agama Kristen berintikan pengajaran yang benar tentang Yesus yang berkarya atas dunia ini. Sehingga dengan pengajaran tersebut warga gereja memiliki kedewasaaan yang benar dan menemukan jati diri yang benar sebagai umat yang percaya. Oleh sebab itu ada beberapa penekanan penting yang harus diperhatikan supaya isi PAK dapat menjiwai kemajemukan yaitu: (1) materi-materi pelajaran yang perlu diperlengkapi untuk menjawab tantangan konteks kemajemukan lingkungan sekolah, yang berorientasi pada konteks masyarakat secara lebih luas; (2) Dalam pendidikan formal, bentuk evaluasi kelas yang harus diseimbangkan antara pencapaian kognitif, afektif maupun psikomotorik. Materi-materi yang bermuatan nilai-nilai multikulturalisme; konsep tentang sesama dan musuh, pacaran beda agama, keluarga campuran, pergaulan dengan siswa berbeda keyakinan, nilai dan norma yang berorientasi sebagai prasangka dan predujice sosial, kerangka filosofis perayaan hari besar keagamaan sebagai simbol dalam agama, gerakan fundamentalisme keagamaan di Indonesia, paham dari tokoh-tokoh agama Indonesia tentang paham kemajemukan, misalnya Gus Dur, pelanggaran HAM di Indonesia. Materi-materi harus mempertimbangkan konteks sekolah sebagai sebuah lingkungan rekayasa, sehingga dapat menjalankan fungsi simulasi masyarakat majemuk. Singkatnya isi PAK yang relevan dalam konteks kemajemukan sangat penting memuat tentang moderasi keberagamaan.

Ketiga, meningkatkan keunggulan dan kualitas pendidikan Kristen dalam mewujudkan integritas masyarakat Kristen dalam pluralitas. Pendidikan Kristen adalah corner stone dari gerejagereja dalam memberitakan Injil. ${ }^{12}$ Kesinambungan suatu gereja di dalam masyarakat hanya dapat terjadi apabila gereja ditopang oleh pendidikan yang relevan dengan konteksnya yaitu Indonesia yang heterogenitas. Pendidikan Kristen harus mengembangkan konotasi positif demi menolong gereja untuk membina sumber daya manusia Indonesia sehingga dapat menghasilkan manusia-manusia Kristen yang berkualitas yaitu manusia yang penuh toleransi, memiliki kemampuan istimewa sehingga dapat memberikan pengabdian yang besar untuk kesejahteraan bangsa dan masyarakat Indonesia.

${ }^{12}$ H.A.R Tilaar, " Arah dan Pengembangan Pendidikan Kristen Menapak Abad ke 21," dalam Partisipasi Kristen dalam Pembangunan Pendidikan di Indonesia Menyongsong Milenium Ketiga, Peny. Weinata sairin (Jakarta: BPK Gunung Mulia, 2000), 27. 


\section{Mengarusutamakan dan Membangun Visi dan Misi Pendidikan Agama Kristen Berbasis Multikultural}

Sebagai salah satu masyarakat heterogen yang ada di belahan dunia ini, konsep ke-Indonesiaan telah merintis satu arah yang dapat memberikan pemecahan terbaik. Harapan tentang syalom dalam kemajemuk tidak akan terwujud Jika masyarakat tidak menghargai kemajemukan sebagai sebuah kekayaan yang dinamik dan cenderung berkembang menjadi totalitarian. Model pendidikan agama bukan hanya sekedar pengayaan ilmu agama, tapi lebih strategis diarahkan bagi pengayaan pengalaman ketuhanan. Model pendidikan agama seperti ini hanya akan terpenuhi jika guru agama bebas dari beban teologis dan beban birokrasi kurikulum. Dalam melakukan pelaksanaan pendidikan agama perlu mempertimbangkan beberapa hal antara lain: pertama, melakukan semacam pergeseran titik perhatian dari agama ke religiusitas. Dalam beragama bukan "to have religion", tetapi "being religious." Dalam "to have religion" yang dipentingkan adalah formalisme agama sebagai kata benda; sedangkan dalam "being religious" yang dipentingkan adalah penghayatan dan aktualisasi terhadap substansi nilai-nilai luhur keagamaan.

Kedua, memasukkan kemajemukan agama, sebagai bagian dari proses dalam memperkaya pengalaman beragama. Hal yang penting dari hal ini adalah mengembangkan sikap proaktif dengan cara mengembangkan sikap saling mengerti, bukan sekedar berdampingan secara damai, tetapi saling mengerti. Ketiga, menekankan pada pembentukan sikap ${ }^{13}$. Oleh karena itu, perlu dilakukan re-orientasi pembelajaran agama dengan lebih menekankan pada pendekatan induktif-partisipatif, ketimbang pendekatan deduktif-normatif. Selain itu, pendidikan agama di sekolah formal umum perlu juga untuk mempertimbangkan model pendidikan agama yang mempelajari tentang agama-agama. Pendidikan agama yang mencari common ground dari semua agama. Persoalan seputar dogma, ritual dan tradisi keagamaan merupakan tugas spesifik agama masing-masing. Aspek demikian yang sangat penting itu berimplikasi juga pada penyelenggaraan pendidikan Kristen yakni PAK yang diselenggarakan di sekolah-sekolah harus lebih menekankan etika dari pada dogmatika. PAK lebih menekankan axiologia (ajaran tentang nilainilai) daripada ontologia (ajaran tentang hakikat sesuatu). PAK harus mengajar bagaimana Tuhan menyapa manusia melalui melalui kehidupan manusia di sekitarnya, manusia yang beraneka ragam, baik warna kulitnya, bahasanya, kepercayaannya, budayanya dan bagaimana manusia merespons atau menanggapinya. ${ }^{14}$ Selain menyajikan bahan-bahan pengetahuan, PAK juga mengusahakan pengalaman dan penghayatan nilai-nilai.

PAK yang berbasis multikulturalisme pada beberapa bagiannya harus pula menjadi media pendidikan perdamaian. Setiap stakeholder pendidikan tidak hanya diberdayakan untuk mampu melakukan rekonsiliasi, akan tetapi melalui pengalaman bersama (kegiatan berkelompok) dapat berbagi dengan yang lain secara terbuka dan saling memberi dukungan. Ideologi PAK dalam masyarakat multikultural Indonesia adalah sebagai wahana pembentukan moral bangsa. Sebagai nilai (norma moral) universal yang ada dalam agama Kristen yang dapat disumbangkan sebagai praktek hidup berbangsa dan bernegara, adalah pencapaian kehidupan yang baik dan benar, sifat dan perilaku jujur, adil dan penuh cinta kasih.

Pendidikan agama berbasis multikulturalisme memungkinkan PAK sebagai media internalisasi nilai. muatan materi dalam media internalisasi nilai adalah tentang bagaimana prinsipprinsip hidup beragama yang saling mendukung dengan konteks bangsa dan negara, yakni konteks multikultural. Materi-materi ini bisa saja merupakan nilai-nilai universal dengan berbahasakan terminalogi yang dekat dengan kekristenan, yang ada dalam seluruh agama, misalnya nilai

\footnotetext{
${ }^{13}$ Y. B. Mangunwijaya, "Pergeseran Titik Berat; dari Keagamaan ke Religiositas" dalam Spiritualitas Baru: Agama dan Aspirasi Rakyat, et al. Ahmad Suaedy, (Yogyakarta: DIAN Interfidei, 1994), 12.

${ }^{14}$ Judo Poerwowidagdo, "Arah Pendidikan Agama Kristen dan Kurikulumnya dalam Memasuki Era Cyber Space Abad XXI", dalam Memperlengkapi bagi Pelayanan dan Pertumbuhan: Kumpulan Karangan Pendidikan Kristiani dalam Rangka Penghormatan kepada Pdt. Prof. Dr. Robert R. Boehlke, Peny. Kadarmanto Hardjowasito, Jan S. Aritonang dan Martin L. Sinaga (Jakarta: BPK Gunung Mulia, 2002), 63.
} 
kasih. Metode pengajaranpun lebih bersifat dialog dan mengembangkan spektrum metode pengajaran yang berbasis pada pengalaman. Hal ini tentunya sejalan dengan prinsip-prinsip utama Pendidikan Agama berdasarkan pendidikan multikultural yang mengedepankan prinsip kasih dan toleransi. Prinsip kasih dan toleransi, yang baru bisa dimengerti dan dipahami secara tepat ketika nilai-nilai itu dipraktekkan.

Sekolah formal sebagai miniatur masyarakat, secara khusus dalam kelas pendidikan agama sebagai media untuk memantapkan pola hidup beragama yang inklusif transformatif. Secara umum, tujuan pendidikan atau pengajaran baru berhasil jika mengena dimensi atau ranah kognitif (intelektual), afektif (sikap/perilaku), dan psikomotorik (keterampilan). Dalam konteks multikultural Indonesia, pelaksanaan PAK sebagai bagian integral dari ideologi pendidikan, juga berfungsi untuk memantapkan internalisasi nilai-nilai Pancasila ke dalam praktek berbangsa dan bernegara Indonesia dari segenap stakeholder PAK di sekolah. PAK bertujuan untuk menghantar segenap stakeholder di sekolah umum menghayati iman sebagai orang Kristen Indonesia, sehingga implikasinya adalah PAK yang diselenggarakan di sekolah umum bertujuan untuk mengkader nara didik yang menjadi betul-betul kristiani dan pada saat yang bersamaan menjadi betul-betul Indonesia ${ }^{15}$.

Langkah-langkah strategis untuk mewujudkan PAK berbasis multikulturalisme dimulai dengan kesiapan merubah paradigma dan pola pikir merespon heterogenitas dalam sistim pendidikan. Wawasan kemajemukan, toleransi, hidup rukun, padangan non mayoritas minoritas sebagai nilai yang mendesak dikembangkan sebagai wujud Falsafah NKRI yaitu Bhineka Tunggal Ika. Paradigma pendidikan agama yang masih eksklusif, dikotomis dan parsial harus diubah menuju pendidikan yang inklusif, integralistik dan holistik. Pendidikan agama menyangkut penumbuhan daya kritis dan kreatif, akar kecerdasan personal, sosial, dan kemanusiaan yang didasarkan pada realitas kemajemukan yang terjadi di lapangan, yakni pendidikan agama yang mengkaji nilainilai universal agama-agama. Pendidikan agama yang diselenggarakan di sekolah-sekolah, seharusnya menjadi pendidikan agama yang "membumi", bukan sebuah pendidikan agama yang "melangit."

Pelaksanaan PAK yang berbasis multikultural di Indonesia tidaklah mudah karena dihadang oleh berbagai tantangan baik fenomena homogenitas, kurikulum maupun guru. Sehingga langkah yang lebih awal dibangun adalah menyusun visi misi PAK yang berorientasi pendidikan multikultural. Sebagai gereja kepunyaan Allah manusia mempunyai iman, pengharapan, kualitas lembaga dan kekuatan penghayatan iman, itulah strategi manusia kemudian kelemahan manusia secara transparan menyadari bahwa SDM masih belum maksimal profesional, komitmen, performance, rendahnya kualitas. Tentang peluang manusia adalah adanya program pemerintah wajib belajar, adanya organisasi majelis pusat pendidikan Kristen dan adanya mitra kerja, sementara ancaman adalah secara eksternal yaitu pluralitas.

Dalam rangka pengembangan pendidikan yang bertitik tolak dari analisis di atas manusia susun visi dan misi. Visi yang relevan adalah berdasarkan kedaulatan Allah yang berinkarnasi dalam Kristus dan kepedulian-Nya terhadap manusia maka pendidikan kristiani yang di dalamnya pengajaran PAK untuk mencerdaskan kehidupan bangsa dan gereja dengan mempersiapkan alumi yang berkualitas, berahklak, mandiri, kreatif, inovatif, dan keuletan dalam pelayanan demi terwujudnya syalom dalam kehidupan bergereja dan bermasyarakat. Sementara Misi memberi arahan terhadap hal-hal yang perlu dilakukan dalam rangkah terwujudnya misi. Sebab itu Pendidikan Agama Kristen bertugas membentuk calon-calon/kader-kader pemimpin yang cukup beriman dan berwawasan luas, berkarakter dan punya visi pelayanan bagi kemanusian dengan suasana damai, pekah terhadap lingkungan sesuai dengan kehendak Allah. Sebab itu

${ }^{15}$ F. C. Lewier, "Pendidikan Agama Kristen yang Partisipatif dan Transformatif dalam Konteks Indonesia", dalam Memperlengkapi bagi Pelayanan dan Pertumbuhan: Kumpulan Karangan Pendidikan Kristiani dalam Rangka Penghormatan kepada Pdt. Prof. Dr. Robert R. Boehlke, Peny. Kadarmanto Hardjowasito, Jan S. Aritonang dan Martin L. Sinaga (Jakarta: BPK Gunung Mulia, 2002), 216. 
pendidikan Agama Kristen memprioritaskan kebutuhan akademik, wawasan iman dan kebersamaan, toleransi dalam hidup berkeluarga, bergereja maupun bermasyarakat.

\section{KESIMPULAN}

Gereja adalah persekutuan yang dibentuk oleh Allah untuk menjalankan misi kerajaan Allah yaitu, memberitakan Injil damai sejahtera tentang karya penyelamatan Allah atas dunia ini. Salah satu wadah gereja memberitakan Injil adalah melalui pengembangan Pendidikan Agama Kristen dengan mempertimbangkan konteks kemajemukan sebagai realitas yang tidak bisa dihindari oleh gereja. PAK sebagai wadah strategis yang digunakan gereja dalam membina warganya untuk mengembangkan integritas dalam konteks majemuk. PAK perlu dikelola secara benar dan tepat melalui langkah strategis yang relevan dengan konteks kemajemukan melalui: (1) Merevitalisasi paradigma berpikir tentang kemajemukan dengan menerima kemajemukan sebagai anugerah Tuhan; (2) Mereinterpretasi strategi pelaksanaan PAK dalam masyarakat yang majemuk; dan (3) Mengarusutamakan dan Membangun visi dan misi PAK berbasis multikultural. Dengan demikian kehadiran gereja melalui PAK dalam kontek masyarakat majemuk bukan menjadi saingan melainkan menjadi berkat pembawa syalom bagi semua.

\section{REFERENSI}

Adiprasetia, Joas. Mencari Dasar Bersama: Etik Global dalam Kajian Postmodernisme dan Pluralisme Agama. Jakarta: BPK Gunung Mulia, 2002.

Banawiratma, J.B. Iman, Pendidikan dan Perubahan Sosial. Yogyakarta: Kanisius, 1991.

Boehlke, Robert R. Sejarah Perkembangan Pikiran dan Praktek Pendidikan Agama Kristen, dari Yohanes Amos Comenius sampai Perkembangan PAK di Indonesia. Jakarta: BPK Gunung Mulia, 2005.

Daniel, Stefanus. Pendidikan Agama Kristen:Kemajemukan. Bandung: Bina Media Informasi, 2009.

Hardjowasito, Kadarmanto. "Pendidikan Agama Kristen dalam konteks Masyarakat Indonesia yang Majemuk," Dalam Berakar di dalam Dia \&Dibangun di atas Dia,Peny. Robert P. Borrong, 107-123 Jakarta: BPK Gunung Mulia,2002.

Hope, Antone S. Pendidikan Kristiani Kontekstual:Mempertimbangkan Realitas Kemajemukan dalam Pendidikan Agama, Terjemahan Mariam sutanto, Jakarta: BPK Gunung Mulia,2010.

Karman, Yonky. "Menggagas Pendidikan Agama Inklusif," Kompas 12 Juni 2002.

Kobong, Theodorus, "Gereja Memasuki Abad ke-21," dalam Seri membangun bangsa Agama Dalam Praksis, Peny. Bambang subandrijo, 176-182 Jakarta: BPK Gunung mulia, 2003.

Mangunwijaya, Y. B. Pergeseran Titik Berat; dari Keagamaan ke Religiositas, dalam Ahmad Suaedy, et al, Spiritualitas Baru: Agama dan Aspirasi Rakyat. Yogyakarta: DIAN Interfidei, 1994.

Lewier, F. C. "Pendidikan Agama Kristen yang Partisipatif dan Transformatif dalam Konteks Indonesia", dalam Memperlengkapi bagi Pelayanan dan Pertumbuhan: Kumpulan Karangan Pendidikan Kristiani dalam Rangka Penghormatan kepada Pdt. Prof. Dr. Robert R. Boehlke, Peny. Kadarmanto Hardjowasito, Jan S. Aritonang dan Martin L. Sinaga, 213217 Jakarta: BPK Gunung Mulia, 2002.

Manggeng, Marthen." Pendidikan Agama Kristen Dalam Masyarakat Majemuk," INTIM: Jurnal Teologi Kontekstual, no.8 (semester genap 2015):21-24.

Poerwowidagdo, Judo. "Arah Pendidikan Agama Kristen dan Kurikulumnya dalam Memasuki Era Cyber Space Abad XXI", dalam Memperlengkapi bagi Pelayanan dan Pertumbuhan: Kumpulan Karangan Pendidikan Kristiani dalam Rangka Penghormatan kepada Pdt. Prof. Dr. Robert R. Boehlke, Peny. Kadarmanto Hardjowasito, Jan S. Aritonang dan Martin L. Sinaga, 62-67 Jakarta: BPK Gunung Mulia, 2002. 
Rantung,Djois Anneke. Pendidikan Agama Kristen dalam Kehidupan Masyarakat Majemuk.

Yogyakarta: Lintang Rasi Aksara Books, 2017.

Santoso, Iman. "Memasuki Abad XXI Umat Kristiani dalam Pergumulan Jati Diri Serta

Pembangunan Bangsa yang Terus menerus," dalam Peran Serta Gereja dalam

Pembangunan Nasional, Peny. Weinata S, 172-176 Jakarta: Sinar Harapan,1998.

Sitompul, Einer M. Gereja Menyingkapi Perubahan.Jakarta: BPK Gunung Mulia, 2004.

Tilaar, H.A.R. "Arah dan Pengembangan Pendidikan Kristen Menapak Abad ke 21," dalam Partisipasi Kristen dalam Pembangunan Pendidikan di Indonesia Menyongsong Milenium Ketiga, Peny. Weinata sairin, 19-31Jakarta: BPK Gunung Mulia, 2000. 